\title{
STORYTELLING SEBAGAI METODE PARENTING UNTUK PENGEMBANGAN KECERDASAN ANAK USIA DINI
}

\author{
Muallifah \\ Fakultas Psikologi \\ Universitas Islam Negeri (UIN) Maulana Malik Ibrahim Malang \\ Jl. Gajayana 50 Malang Telp. 0341-558916 \\ email : aliefaha@gmail.com
}

\begin{abstract}
Abstrak - Usia dini antara 0-6 tahun merupakan tahap perkembangan anak yang paling penting. Hal ini dikarenakan usia dini adalah masa keemasan (golden age) bagi perkembangan otak anak. Terdapat berbagai bentuk pendidikan yang bisa diberikan kepada anak-anak sejak usia dini. Mulai dari metode bernyanyi, bermain, bercerita dan karya wisata. Beberapa penelitian menyebutkan metode bercerita (storytelling) adalah metode yang efektif dan paling banyak digemari pada usia anak. Alasan mengapa (storytelling) dianggap efektif dalam memberikan pendidikan kepada anak. Pertama, cerita pada umumnya lebih berkesan dari pada nasehat, sehingga pada umumnya cerita terekam jauh lebih kuat dalam memori manusia. Kedua, melalui (storytelling) anak diajarkan mengambil hikmah. Penggunaan metode bercerita akan membuat anak lebih nyaman dari pada diceramahi dengan nasehat. Untuk menciptakan anak cerdas dan sukses diperlukan usaha yang maksimal, termasuk model parenting (pola asuh) yang diterapkan kepada anak. Parenting yang bisa mengembangkan potensi dan kreatifitas anak adalah model parenting authoritative. Storytelling (metode bercerita) mampu menstimulasi berbagai kecerdasan anak sejak usia dini. Diantaranya, storytelling mampu meningkatkan kecerdasan bahasa anak, kreatifitas dan menanamkan moral pada anak usia dini. Namun yang perlu diperhatikan adalah tahap kognitif anak usia dini masih pada tahap operasional kongkrit, maka bentuk cerita yang dijadikan sebagai metode bercerita harus menyesuaikan dengan kemampuan anak.
\end{abstract}

Keyword: Parenting, Storytelling, authoritative.

PSIKOISLAMIKA. Jurnal Psikologi Islam (JPI) copyright @ 2013 Laboratorium Penelitian, Kajian Psikologi Islam dan Penerbitan. Volume 10. Nomor 1, Tahun 2013

\section{PENDAHULUAN}

Anak merupakan investasi yang sangat berharga bagi orangtua di masa depan. Semua orangtua pasti menginginkan anaknya sukses, oleh karena itu berbagai upaya yang dilakukan orangtua untuk mewujudkannya. Mulai dari memperhatikan asupan gizi yang dikonsumsi oleh anak, memenuhi apa yang dibutuhkan sampai pada memberikan pendidikan kepada anak.

Mencetak anak sukses bukan hanya tergantung pada lembaga pendidikan formal, melainkan bisa kita mulai dengan memberikan pendidikan di dalam keluarga sejak usia dini. Menurut Piaget, salah satu tokoh psikologi menyatakan bahwa usia dini (0-6 tahun) merupakan tahap perkembangan anak yang paling penting. Hal ini dikarenakan usia dini adalah masa keemasan (golden age) bagi perkembangan otak anak. Kosasih (2008) menambahkan bahwa "The Golden Age" adalah masa emas yang tepat untuk diberikan stimulasi. Pada masa ini perkembangan motorik anak semakin baik, sejalan dengan perkembangan kognitifnya yang mulai kreatif dan imajinatif. Daya imajinatif yang tinggi, membuat anak semakin suka menemukan hal-hal baru. Sejalan dengan perkembangan kognitifnya informasi yang diberikan kepada anak secara berulang-ulang akan tersimpan dalam waktu yang lama (Koyan, 2000). Hal ini menunjukkan bahwa potensi dan kemampuan yang dimiliki oleh anak usia dini harus dikembangkan, agar pendidikan yang diberikan bisa optimal. 
Berbagai bentuk pendidikan yang bisa diberikan kepada anak-anak sejak usia dini. Mulai dari metode bernyanyi, bermain, bercerita dan karya wisata. Masing-masing metode mempunyai kelemahan dan kelebihan. Namun banyak penelitian, diantaranya penelitian yang dilakukan oleh Murdiono pada tahun 2008 dari beberapa metode yang digunakan tersebut, metode bercerita (storytelling) adalah metode yang efektif dan paling banyak digemari pada usia anak.

Ada beberapa alasan mengapa (storytelling) dianggap efektif dalam memberikan pendidikan kepada anak. Pertama, cerita pada umumnya lebih berkesan dari pada nasehat, sehingga pada umumnya cerita terekam jauh lebih kuat dalam memori manusia. Kedua, melalui (storytelling) anak diajarkan mengambil hikmah. Penggunaan metode bercerita akan membuat anak lebih nyaman dari pada diceramahi dengan nasehat.

Sementara itu, perlu diingat anak usia dini memiliki karakter yang khas, mereka lebih suka bermain dan bersenang-senang. Maka dalam pengajaran pada anak dibutuhkan metode-metode yang sesuai dengan karakter anak agar proses pengajaran tersebut bisa maksimal. Di dalam (storytelling) anak-anak dikenalkan dengan berbagai karakter unik yang ada di dalamnya. Selain itu, anak lebih merasa senang dari pada model pembelajaran ceramah.

Michael (2009) menyatakan bahwa bercerita merupakan metode yang sangat penting dalam mengembangkan kemampuan bahasa dan kognitif pada anak usia dini. Hal senada juga diungkapkan oleh Moeslichaton (2004) selain mengembangkan bahasa dan kognitif anak, metode bercerita (storytelling) juga memiliki beberapa manfaat, diantaranya; (1) melalui cerita kita bisa menyisipkan sifat empati, kejujuran, kesetiaan dan keramahan, ketulusan, (2) memberikan sejumlah pengetahuan sosia, moral dan lain sebagainya, (3) melatih anak belajar mendengarkan apa yang disampaikan, (4) membuat anak bsia mengembangkan aspek psikomotor, kognitif dan afektif, (5) metode bercerita mampu meningkatkan imajinasi dan kreatifitas anak.

Dari berbagai hasil penelitian yang sudah dikemukakan di atas, dapat difahami bahwa peran metode bercerita (storytelling) bagi anak usia dini mampu menumbuhkembangkan potensi-potensi yang dimiliki oleh anak. Baik dari aspek psikomotor, kognitif, afeksi maupun moral anak. Untuk itu artikel ini membahas tentang metode storytelling sebagai metode parenting education untuk mengembangkan kecerdasan pada anak usia dini.

\section{KERANGKA KERJA TEORITIK} Storytelling

Secara bahasa Storytelling adalah interaktif, pendengar mendengarkan cerita yang disampaikan. Metode bercerita (storytelling) merupakan sebuah metode yang dilakukan oleh seseorang, dengan cara membaca. Menurut Henny (2007) dalam proses pembelajaran storytelling atau metode bercerita merupakan salah satu metode untuk meningkatkan kemampuan berbicara. Bercerita bukan hanya berbagi pengetahuan tentang isi cerita dan pengalaman, tetapi juga memberikan suatu nasihat kepada anak. Selain itu bercerita juga dapat memperkenalkan anak kepada nila-nilai moral dan sosial.

Hal senada juga diungkapkan oleh Brewer (2007) menggambarkan storytelling adalah bertutur dengan intonasi yang jelas, menceritakan sesuatu yang berkesan, menarik, punya nilai-nilai khusus dan punya tujuan khusus. Menurut Henny (2007) melalui metode cerita, anak tidak akan pernah kehabisan akal, karena cerita akan menimbulkan dampak positif, antara lain; (a) melatih daya tangkap, (b) melatih daya pikir, (c) melatih daya konsentrasi, (d) membantu perkembangan imajinasi. (e) menciptakan suasana yang menyenangkan. Wuryandani (2006) dalam penelitiannya juga menyebutkan bahwa metode bercerita (storytelling) memiliki beberapa dampak positif, diantaranya; (a) menimbulkan minat untuk membaca bagi anak-anak, (b) meningkatkan minat baca, (c) membentuk budaya membaca.

Ketika bercerita, pencerita dapat melakukan dengan teknik yang menarik agar pesan yang disampaikan oleh penulis atau pengarang cerita dapat disampaikan. Hal ini bisa dilakukan dengan cara; pengucapan atau peniruan suara, intonasi atau nada suara, penghayatan watak tokoh cerita, ekspresi cerita, gerak dan penampilan, kemampuan bahasa yang komunikatif.

\section{Parenting (Pola Asuh)}

Kata parenting secara bahasa sering diartikan sebagai kemampuan atau keterampilan yang dimiliki oleh orang tua dalam mengasuh anak. Shohib (1998) menyatakan bahwa parenting merupakan cara yang digunakan oleh orang tua untuk mengasuh anak baik secara langsung maupun tidak langsung.

Sementara Baumrind (1978) menyatakan pola asuh pada prinsipnya merupakan parental control yakni bagaimana orang tua mengontrol, membimbing, mendampingi anak-anaknya untuk melaksanakan tugas-tugas perkembangannya dan menuju pada proses pendewasaan. Hal senada 
juga diungkapkan oleh Kohn (dalam Casmini, 2007) mengatakan bahwa pola asuh atau pengasuhan merupakan cara orangtua berinteraksi dengan anak yang meliputi pemberian aturan, hadiah, hukuman dan pemberian perhatian, serta tanggapan orangtua terhadap setiap prilaku anak. Sedangkan Karen (2008) menyatakan bahwa kualitas pola asuh yang baik adalah kemampuan orangtua untuk memonitor segala aktivitas anak, sehingga ketika anak dalam keadaan terpuruk orangtua mampu memberikan support dan memperlakukan anak dengan baik, sesuai dengan kondisi anaknya.

Dari beberapa definisi parenting di atas menunjukkan bahwa parenting mencakup beberapa pemahaman, diantaranya: (a) pengasuhan bertujuan untuk mendorong pertumbuhan dan perkembangan anak secara optimal, baik secara fisik, mental maupun sosial, (b) pengasuhan merupakan sebuah proses interaksi yang terus menerus antara orang tua dengan anak, (c) pengasuhan adalah sebuah proses sosialisasi, (d) sebagai sebuah proses interaksi dan sosialisasi proses pengasuhan tidak bisa dilepaskan dari sosial budaya dimana anak dibesarkan.

Ada beberapa tipe pengasuhan dalam keluarga. Meurut Baumrind (1978), pola asuh (parenting) ada tiga macam, yaitu (1) pola asuh authoritarian, (2) pola asuh authoritative, (3) pola asuh permisive

Menurut Baumrind (1978) bentuk pola asuh authoritarian memiliki ciri-ciri antara lain: (a) orangtua dalam memperlakukan anaknya bersifat tegas, (b) suka menghukum anak yang dianggap tidak sesuai dengan keinginan orangtua, (c) kurang memiliki kasih sayang, (d) mudah menyalahkan segala aktivitas anak terutama ketika anak ingin berlaku kreatif. Pada prilaku authoritarian, orangtua suka memaksakan anak-anaknya untuk patuh terhadap aturan-aturan yang sudah ditetapkan oleh orangtua, berusaha membentuk tingkah laku, sikap serta cenderung mengekang keinginan anak-anaknya. Orangtua tidak mendorong anak untuk mandiri, jarang memberikan pujian ketika anak sudah mendapatkan prestasi atau melakukan sesuatu yang baik, hak anak sangat dibatasi tetapi dituntut untuk mempunyai tanggung jawab sebagaimana dengan halnya orang dewasa.

Sedangkan pola authoritative mempunyai ciriciri antara lain: (a) hak dan kewajiban antara anak dan orangtua diberikan secara seimbang, (b) mereka saling melengkapi satu sama lain, orangtua yang menerima dan melibatkan anak dalam mengambil keputusan yang terkait dengan kepentingan keluarga, (c) Memiliki tingkat pengendalian tinggi dan mengharuskan anak-anaknya bertindak pada tingkat intelektual dan sosial sesuai usia dan kemampuan mereka. Tetapi mereka tetap memberi kehangatan, bimbingan, dan komunikasi dua arah, (d) Memberikan penjelasan dan alasan atas hukuman dan larangan yang diberikan oleh orangtua kepada anak, (e) selalu mendukung apa yang dilakukan oleh anak, tanpa membatasi segala potensi yang dimilikinya serta kreativitasnya namun tetap membimbing dan mengarahkan anak-anaknya.

Adapun pola asuh permisive memiliki ciri-ciri antara lain: (a) orangtua memberikan kebebasan kepada anak seluas mungkin, (b) anak tidak dituntut untuk belajar bertanggung jawab, (c) anak diberikan hak yang sama dengan orang dewasa, anak diberikan kebebasan yang seluas-luasnya untuk mengatur diri sendiri, (d) orangtua tidak banyak mengatur dan tidak banyak mengontrol, sehingga anak tidak diberi kesempatan untuk mandiri dan mengatur diri sendiri dan diberikan kewenangan untuk mengontrol dirinya sendiri.

Dari pemaparan model pengasuhan di atas bisa diketahui bahwa model pola asuh model otoriatatif ini mampu meningkatkan psikososial anak, lebih efektif memberikan kebebasan anak dalam mengekspresikan dan mengaktualisasikan potensinya dan membuat anak menjadi lebih kreatif. Statement ini didukung oleh hasil penelitian yang dilakukan oleh Dr. M. Enoch Markum dalam Disertasinya, membuktikan, pola asuh otoritatif sangat efektif untuk menunjang anak berprestasi tinggi dan lebih kreatif.

\section{DISKUSI}

\section{Storytelling sebagai Metode Mencerdaskan Anak}

Menurut kedokteran optimalisasi perkembangan kecerdasan dimulai dari anak baru lahir sampai usia 5 tahun atau sering disebut dengan usia golden age (usia emas). Hal ini menunjukkan bahwa hampir 50 persen potensi kecerdasan anak sudah terbentuk pada usia empat tahun, kemudian secara bertahap mencapai 80 persen pada usia delapan tahun.

Untuk mencerdaskan anak bisa dilakukan dengan memberikan stimulasi. Diantara cara yang paling mudah adalah dengan membacakan buku pada anak, terutama sejak usia dini (0-6 tahun). Dengan cara demikian anak bisa merespon informasi yang disampaikan dalam cerita dan otak menyerap informasi yang terkandung di dalamnya. Seperti yang sudah diketahui bahwa usia balita disebut sebagai the golden age, dimana kualitas otak 
anak sangat ditentukan oleh tiga tahun pertama kehidupannya. Saat lahir, otak memiliki satu triliun sel otak. Setelah kelahiran, otak bayi menghasilkan bertriliun-triliun sambungan (sinap) antar neuron yang banyaknya melebihi kebutuhan. Proses inilah yang membentuk pengalaman dan akan dibawanya seumur hidup.

Berdasarkan potensi yang dimiliki oleh anak tersebut, maka pemberian stimulus yang tidak maksimal juga akan membuat potensi tidak berkembang dengan optimal. Untuk mencapai perkembangan potensi anak secara optimal, seharusnya stimulasi dilakukan sejak anak usia dini.

Banyak wacana yang mengatakan akhir-akhir ini orangtua banyak lebih memilih cara yang lebih instan dan mudah dalam melaksanakan pengasuhan anak. Hal ini ditunjukkan dengan kurang adanya kontrol dan dampingan orangtua terhadap pergaulan anak, kegiatan anak dan tontonan program televisi yang disaksikan oleh anak-anak. Pengaruh media terhadap anak makin besar, teknologi semakin canggih \& intensitasnya semakin tinggi. Sementara orangtua tidak memiliki banyak waktu yang cukup untuk memperhatikan, mendampingi \& mengawasi anak. Anak lebih banyak menghabiskan waktu menonton televisi dari pada melakukan aktifitas lain yang mampu mengembangkan kreatifitasnya.

Masih banyak orangtua memandang bahwa beberapa program televisi mampu menggantikan perannya untuk membuat anak menjadi lebih diam dan menikmati dengan berbagai bentuk visualnya. Padahal banyak penelitian yang menyatakan bahwa televisi memiliki beberapa dampak negatif terhadap tumbuh kembang anak. Diantaranya, penelitian Prof Sarlito menyebutkan bahwa banyaknya waktu yang dihabiskan oleh anak-anak untuk melihat televisi menyebabkan anak lebih pasif, sulit berinteraksi, lebih agresif dan sulit berkomunikasi serta kreatifitas anak menjadi lebih sempit. Penelitian lain menyebutkan bahwa melihat televisi lebih dari 6 jam sehari bisa menimbulkan dampak negatif pada anak, diantaranya: mendorong anak menjadi konsumtif, berpengaruh terhadap sikap, mengurangi semangat belajar, membentuk pola pikir sederhana, mengurangi konsentrasi, mengurangi kreativitas dan lain sebagainya (Adhim, 2006).

Model parenting atau pengasuhan dalam keluarga merupakan dasar yang sangat penting bagi perkembangan dan kesuksesan anak (Karen \& Claudio, 2008). Oleh karena itu, bagaimana kemudian model pengasuhan yang diberikan kepada anak bisa sesuai dengan pengembangan potensi yang dimiliki anak, termasuk pemberian stimulasi agar berbagai kecerdasan anak bisa berkembang dengan baik, mengontrol, mendampingi apa yang disaksikan dan apa yang dilakukan oleh anak. Jadi model pola asuh authoritative merupakan bentuk pola asuh yang tetap menstimulasi dan meningkatkan kecerdasan anak.

Berbagai cara bisa dilakukan oleh orangtua untuk menstimulasi kecerdasan anak, diantaranya; mendengarkan musik, melihat atau mengalami secara langsung dalam proses pembelajaran. Namun banyak penelitian menyatakan bahwa metode yang tepat dan efektif untuk menstimulasi berbagai kecerdasan anak usia dini adalah metode storytelling. Dalam kegiatan storytelling, proses bercerita menjadi sangat penting, karena dari proses inilah nilai atau pesan dari cerita tersebut dapat sampai pada anak. Pada saat proses storytelling berlangsung terjadi sebuah penyerapan pengetahuan yang disampaikan orangtua kepada anak.

\section{Storytelling Meningkatkan Kecerdasan Bahasa Anak}

Dari berbagai penelitian, storytelling digunakan sebagai metode yang mampu untuk menstimulasi dan meningkatkan kemampuan bahasa verbal anak. Melatih dan merangsang kemampuan berbahasa anak merupakan salah satu tugas penting bagi orangtua. Salah satu metode yang tepat menurut kriteria di atas adalah dengan storytelling atau metode bercerita. Dalam Cerita pada dasarnya memiliki struktur kata dan bahasa yang lengkap serta menyeluruh yang mana di dalamnya sudah terdapat sistem aturan bahasa yang mencakup fonologi, morfologi, sintaksis, semantik (Santrock, 2007). Lenox (2000) juga menjelaskan efek lain dari storytelling adalah alat yang sangat kuat untuk meningkatkan pemahaman diri anak dan orang lain disekitarnya.

Hal ini dijelaskan oleh Colon (1997 dalam Isbell, Sobol, 2004) yang menyatakan bahwa dalam storytelling mampu mengajari anak untuk mendengar, membantu membangun keterampilan komunikasi oral dan tulisan, dan mengembangkan pemahaman dari cerita skema. Storytelling juga membantu mengembangkan kelancaran, menambah perbendaharaan kata, dan membantu mengingat kata. Selain itu, melalui Storytelling anak menjadi tertarik untuk bertanya ketika mereka tidak memahami isi cerita, dari proses inilah kemudian perbendaharaan kata bertambah. Dari berbagai penelitian di atas, dapatlah kita ketahui bahwa metode storytelling 
bisa digunakan untuk meningkatkan kecerdasan bahasa anak usia dini.

\section{Storytelling Membuat Anak Kreatif}

Kreatifitas pada anak usia dini merupakan kemampuan yang bukan hanya ada begitu saja, tetapi membutuhkan stimulasi dari pihak luar termasuk orangtuanya. Ford (2007) menjelaskan hasil pengalamannya mengajar menggunakan metode storytelling yang disesuaikan dengan karakteristik anak, dimana murid-muridnya memiliki kekurangan dalam memecahkan masalah secara kreatiaf. Melalui storytelling Ford mengungkapkan bahwa anak didiknya menjadi lebih kreatif dalam menjawab soal dan memecahkan masalah. Roney (1996 dalam Isbell, Sobol, 2004) menjelaskan bahwa storytelling mampu meningkatkan kreatifitas anak, karena di dalamnya membuat pencerita berfikir bagaimana cerita itu disampaikan dengan model yang berbeda dan kreatif. Misalnya, ketika membacakan buku tentang warna dan bentuk buah-buahan, orang tua dapat mengambil buah yang asli dan menjelaskannya pada anak. Anak dapat merasakan tekstur buah, dan mengetahui warna aslinya. Selain itu, aspek yang harus diperhatikan agar berjalan dengan efektif adalah memiliki komunikasi dua arah (antara storyteller dan pendengar).

\section{Storytelling Mengajarkan Moral pada Anak Usia Dini}

Dalam storytelling juga mengandung unsur modelling (teladan) yang bisa diberikan kepada anak melalui ceritanya. Sebagai orangtua pasti menginginkan sikap dan prilaku anak memiliki moral yang baik. Untuk mengajarkan moral yang positif pada anak usia dini tidak mungkin dengan memberikan ceramah yang panjang dan memarahi jika anak berbuat salah. Salah satu metode yang disenangi anak tanpa harus memaksanya adalah dengan bercerita (storytelling). Di dalamnya orangtua bisa memberikan cerita yang mengandung unsur-unsur moral dan mengajarkan nilai-nilai moral yang baik kepada anak. Misalnya, sambil bercerita orangtua mengajarkan anak untuk berdo'a setiap sebelum dan sesudah makan, berterimakasih dan bersyukur dengan nikmat yang diterima, dan bersikap sopan santun kepada orang lain. Melalui storytelling anak tanpa merasa diguruhi dan dinasehati dengan katakata yang menakutkan. Dengan demikian orangtua bisa mengajarkan dan menanamkan moral kepada anak sejak usia dini.

Dalam menggunakan Storytelling (metode bercerita) hendaknya menyesuaikan dengan level kognitif anak. Dimana pada usia dini, level kognitif mereka masih pada operasional kongrit (Santrock, 2007). Jadi cerita yang dibacakan atau disampaikan haruslah menyesuaikan tingkat kemampuan kognitif anak.

\section{Membangun Attachment (Kelekatan) Antara Orangtua dan Anak dalam Storytelling}

Dalam storytelling bukan hanya bisa meningkatkan berbagai kecerdasan pada diri anak, namun melalui metode cerita juga mampu meningkatkan kelekatan (attachment) antara orangtua dan anak. Karena dalam storytelling orangtua mampu membangun komunikasi efektif, memberikan suasana menyenangkan dan membuat anak merasa nyaman dengan berbagai cerita yang diberikan. Selain itu, melalui storytelling orangtua juga memberikan perhatian yang dibutuhkan oleh anak, baik secara emosional meupun secara sosial.

Brewer (2007) menyatakan bahwa melalui storytelling mampu membangun hubungan yang harmonis dan dekat antara orangtua dan anak. Semakin bagus kelekatan yang dibangun antara orangtua dan anak, maka semakin bagus pula stimulasi kecerdasan yang diberikan kepada anak. Hal ini tentunya bisa meningkatkan kecerdasan anak.

\section{KESIMPULAN}

Anak adalah anugrah dari tuhan yang luar biasa, kesuksesan anak merupakan dambaan dan harapan semua orangtua. Untuk menciptakan anak cerdas dan sukses diperlukan usaha yang maksimal, termasuk model parenting (pola asuh) yang diterapkan kepada anak. Parenting yang bisa mengembangkan potensi dan kreatifitas anak adalah model parenting authoritative. Selain itu, untuk membuat anak cerdas bisa diawali dengan memberikan stimulasi sejak usia dini. Karena pada masa ini anak disebut sebagai masa golden age (usia keemasan), dimana stimulasi sangat tepat diberikan untuk mengembangkan kecerdasannya. Berbagai penelitian menyebutkan bahwa storytelling (metode bercerita) mampu menstimulasi berbagai kecerdasan anak sejak usia dini. Diantaranya, storytelling mampu meningkatkan kecerdasan bahasa anak, kreatifitas dan menanamkan moral pada anak usia dini. Namun yang perlu diperhatikan adalah tahap kognitif anak usia dini masih pada tahap operasional kongkrit, maka bentuk cerita 
yang dijadikan sebagai metode bercerita harus menyesuaikan dengan kemampuan anak.

\section{DAFTAR PUSTAKA}

Adhim, F. 2006. Positive Parenting cara-cara Islami Mengembangkan Karakter positif Pada Anak. Bandung: Mizan Media Utama

Baumrind, D. 1978. Current Pattern Of Parental Autority, Development Psychology. Monograph 4. No. 1

Brewer, Jo An. 2007. Introduction to Early Child-Nood Education Presholl Throught Primary Grades. United States of Amerika: Pearson

Casmini. 2007. Emotional Parenting Dasar-dasar Pengasuhan Kecerdasan Emosi Anak. Yogyakarta: Nuansa Aksara

Ford, T. 2007. The Power of Story in Building Character and Community. http://academic. evergreen.edu/c/chambreb/Power\%20 of\%20Story\%20 Reader\%2007.pdf

Henny, S. 2007. Cara Bercerita Yang Efektif dan Menarik. Bandung: Disdik Propinsi Jawa Barat.

Isbell,R. dkk .2004. The Effects of Storytelling and Story Reading on the Oral Language Complexity and Story Comprehension of Young Children. Early Childhood Education Journal, Vol. 32. No. 3.

Karen, M. \& Claudio. 2008. Pathway to
Competence: Adversity the roles of Parenting Quality and Social Support. The journal of psychology, 142 (4), 427-443. Heldref Publication.

Kosasih. 2008. Perkembangan dan Pengembangan Anak di Usia Taman Kanak-Kanak. Jakarta: Grasindo.

Koyan, I. 2000. Pendidikan Moral Pendekatan Lintas Budaya. Jakarta: Depdiknas.

Lenox, F. 2000. Storytelling for Young Children in a Multicultural World. Early Childhood Education Journal. Vol. 28. No. 2.

Michael L. 2009. Teaching Your Children. New Jersey: Person Education

Moelichatoen. 2004. Metode Pengajaran di taman Kanak-Kanak. Jakarta: Rineka Cipta

Murdiono, M. 2008. Metode Penanaman Nilai Moral untuk Anak Usia Dini. Yogyakarta: Universitas Negri Yogyakarta.

Rakhmat, 2007. Retorika Modern (Pendekatan Praktis). Bandung: Remaja Rosdakarya

Santrock, J, W. 2007. Psikologi Pendidikan (terjemahan). Jakarta: Kencana Prenada Media Group

Shohib. 1998. Pola Asuh Orang Tua. Jakarta: Rineka Cipta

Wuryandani, W. 2006. Strategi Bercerita Untuk Menanamkan Nilai Moral Pada Anak Usia Dini. Majalah Ilmiah Pembelajaran. Volume 2. Nomor 2. 